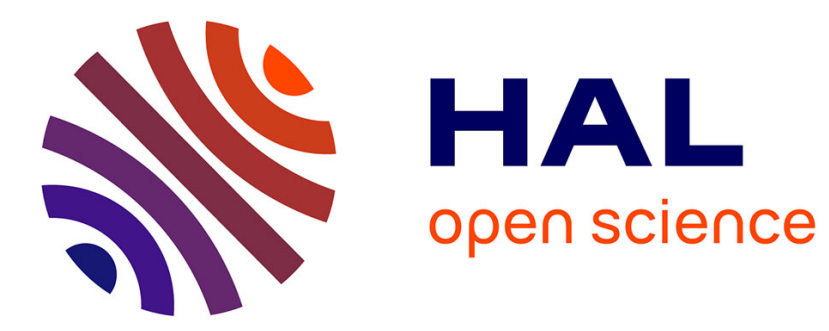

\title{
Cyanobacteria and cyanotoxins in estuarine water and sediment
}

\author{
M. Bormans, V. Savar, B. Legrand, E. Mineaud, E. Robert, E. Lance, Z.
}

Amzil

\section{- To cite this version:}

M. Bormans, V. Savar, B. Legrand, E. Mineaud, E. Robert, et al.. Cyanobacteria and cyanotoxins in estuarine water and sediment. Aquatic Ecology, 2020, 54 (2), pp.625-640. 10.1007/s10452-020-09764y . hal-02862833

\section{HAL Id: hal-02862833 \\ https://hal-univ-rennes1.archives-ouvertes.fr/hal-02862833}

Submitted on 25 Jun 2020

HAL is a multi-disciplinary open access archive for the deposit and dissemination of scientific research documents, whether they are published or not. The documents may come from teaching and research institutions in France or abroad, or from public or private research centers.
L'archive ouverte pluridisciplinaire HAL, est destinée au dépôt et à la diffusion de documents scientifiques de niveau recherche, publiés ou non, émanant des établissements d'enseignement et de recherche français ou étrangers, des laboratoires publics ou privés. 


\title{
Cyanobacteria and cyanotoxins in estuarine water and sediment
}

\author{
Myriam Bormans*1, Véronique Savar ${ }^{2}$, Benjamin Legrand ${ }^{3}$, Emilien Mineaud ${ }^{1}$, \\ Elise Robert ${ }^{2}$, Emilie Lance ${ }^{45}$, Zouher Amzil ${ }^{2}$ \\ 1 Univ Rennes, CNRS, ECOBIO - UMR 6553, F-35000 Rennes, France \\ 2 IFREMER, Phycotoxins Laboratory, F-44311 Nantes, France
}

${ }^{3}$ ATHOS Environnement, 112 avenue du Brézet, 63100 Clermont Ferrand, France

4 UMR-I 02 SEBIO, Bat 18, Campus du Moulin de la Housse, BP 1039, 51687 REIMS Cedex 2, France

5 UMR 7245 MNHN/CNRS MCAM, équipe CCE, Muséum National d'Histoire Naturelle, 12 rue Buffon, F-75231, Paris.

*Corresponding author: myriam.bormans@univ-rennes1.fr tel : +33223235979

Key words: toxic cyanobacteria, microcystin, colonies, estuary, sediment

\section{Abstract}

While transfer of freshwater cyanobacteria to estuaries has been observed worldwide, the associated transfer of cyanotoxins is less often reported, in particular the sediment contribution. During fall 2018, we monitored the co-occurrence of cyanobacteria and microcystin (MC) in both the water column and in surface sediments at 5 stations along a river continuum, from a freshwater reservoir to the coastal area in Brittany, France. Cyanobacteria dominated the phytoplankton community in the water column with high densities at the freshwater sites. Microcystis cells and intracellular MC transfer to estuarine and marine sites were observed with decreasing concentrations in accordance with flow dilution. Extracellular MC showed the opposite trend and increased from upstream to downstream in accordance with the lysing of the cells at elevated salinities. Surface sediment samples contained high densities of colonial Microcystis in freshwater and with decreasing concentrations along the salinity gradient, similarly to cells concentrations in the water column. Intracellular MC was detected in sediment at all sites except at the marine outlet suggesting the survival of intact cells. Extracellular MC concentrations in sediment were up to 5 times higher than intracellular 
concentrations suggesting incomplete $\mathrm{MC}$ degradation. mcyB genes were present at all sites while mcyA genes were absent at the marine outlet suggesting the presence of toxic strains along the estuary. The high densities of intact colonies of potentially toxic Microcystis in the estuarine sediment strongly suggest that sediments can act as an inoculum of cyanobacteria and cyanotoxins in estuaries.

\section{Introduction}

Cyanobacterial blooms have been reported worldwide (Merel et al. 2013) and their proliferations have been increasing in recent years as a result of anthropogenic activities including eutrophication and climate warming (O'Neil et al. 2012; Rigosi et al. 2014; Paerl 2018). Freshwater cyanobacteria produce a large variety of toxins (including hepatotoxins, neurotoxins, dermatotoxins) which have strong negative impact on animal and human health (Lance et al. 2010; Metcalf and Codd 2012; Wood 2016 for a review, Meriluoto et al. 2017). Among the diversity of cyanotoxins, microcystin (MC) is largely recognized as the most common and widespread in freshwater ecosystems (Harke et al. 2016). The general structure of those cyclic heptapeptides includes a specific beta amino acid-3-amino-9-methoxy-2,6,8trimethyl-10-phenyl-4,6-decadienoic acid-Adda (Ortiz et al. 2017; Tillett et al. 2000) as well as two amino acids that can vary leading to the identification of more than 250 MC variants (Puddick et al. 2014). The regulation and synthesis of MC, as well as its ecological role, are complex and not yet fully understood (Omidi et al. 2017).

The transfer of freshwater cyanobacteria to estuaries has been observed worldwide (Preece et al. 2017 for a review), in Africa (Ndlela et al. 2016), USA (e.g. Lehman et al. 2005; Peacock et al. 2018), South America (e.g. Dörr et al. 2010), Australia (Robson and Hamilton 2003; Orr et al. 2004), Europe (e.g. Verspagen et al. 2006; Tonk et al. 2007; Paldavičiene et al. 2009; Bormans et al. 2019), and Turkey (Taş et al. 2006). The majority of these studies reported on the cyanobacterial transfer being dominated by Microcystis aeruginosa demonstrating a certain salt tolerance of that species. The associated transfer of intracellular or extracellular MC along the river continuum was less often reported (Preece et al. 2017). In particular MC transfer to the coastal environment resulting from freshwater discharge from an upstream 
reservoir has only been reported in Italy (De Pace et al. 2014), Japan (Umehara et al. 2012; 2015) and recently in France (Bormans et al. 2019).

To our knowledge, MC occurrence in estuarine sediment has only been reported in Isahaya Bay, Japan (Umehara et al. 2012, 2015), and in sub-estuaries of the Baltic Sea (Paldaviciene et al. 2015) and Chesapeake Bay, USA (Bukaveckas et al. 2017) while cyanobacterial (e.g. Microcystis) occurrence in estuarine sediment has never been demonstrated. Hence, given the demonstrated contamination of estuarine and marine benthic and pelagic organisms (Preece et al. 2015; Gibble et al. 2016; Bukaveckas et al. 2017, 2018), as well as the high potential for tidal derived sediment resuspension in estuaries (Labry et al. 2016) we wanted to investigate the sediment's contribution of a French estuary as a potential source/sink of both cyanobacteria and MC.

Here we report on the co-occurrence of both cyanobacteria and microcystin in the water column and in surface sediment along a river continuum from a freshwater reservoir discharge to the marine environment during fall 2018. This study is part of a larger project aiming at the evaluation of the potential risk of contamination of aquatic organisms (i.e. bivalves) by cyanotoxins during transfer from a freshwater reservoir to an estuary mouth in Brittany, France. We present results on phytoplankton/cyanobacterial species composition, and concentrations of different variants of $\mathrm{MC}$ both in intracellular and extracellular forms. The quantification of those two forms of toxins are necessary as we anticipate gradual cells lysing along the salinity gradient. We also report on the presence of microcystin producing genes mcy $A$ and mcyB together with the ana $C$ gene in surface sediment to assess the potential toxicity of estuarine sediment.

\section{Materials and methods}

\subsection{Study site and sampling protocols}

We chose to investigate a site in Brittany where most of the French agricultural lands are located and where reports of toxic blooms have been numerous in freshwater lakes and reservoirs (Vezie et al. 1998; Brient et al. 2009; Pitois et al. 2018). Moreover, in Brittany, most rivers have short residence times (Fraisse et al, 2013) 
and as a result reservoirs are generally close to marine outlets. The study site is

109 located in the Morbihan (Brittany, France) along a continuum of moderate length $(<10$

$110 \mathrm{~km})$, from the Pen Mur freshwater reservoir upstream through the Saint Eloi River,

111 the Pen Lann estuary and the marine outlet (Fig. 1). Pen Mur reservoir is used for

112 drinking water and it is monitored by the Regional Health Agency (ARS). The

113 reservoir experiences recurrent intense cyanobacterial blooms dominated by the

114 genus Microcystis (Bormans et al. 2019). Freshwater discharge from the reservoir to

115 the estuary is frequently observed but not monitored and therefore not quantified.

117 During fall 2018, we sampled on October 10, at 5 stations along a freshwater-marine 118 gradient, where $\mathrm{F} 1$ in the Pen Mur reservoir and F2 in the river downstream of the 119 reservoir are both in the freshwater section, E1 and E2 are located in the estuarine 120 section, and the site $\mathrm{M}$ is located at the entrance of the marine section (Fig. 1). In 121 particular, we sampled the 3 downstream stations within 1 hour of low tide to 122 maximize the freshwater discharge and minimize the tidal contribution.

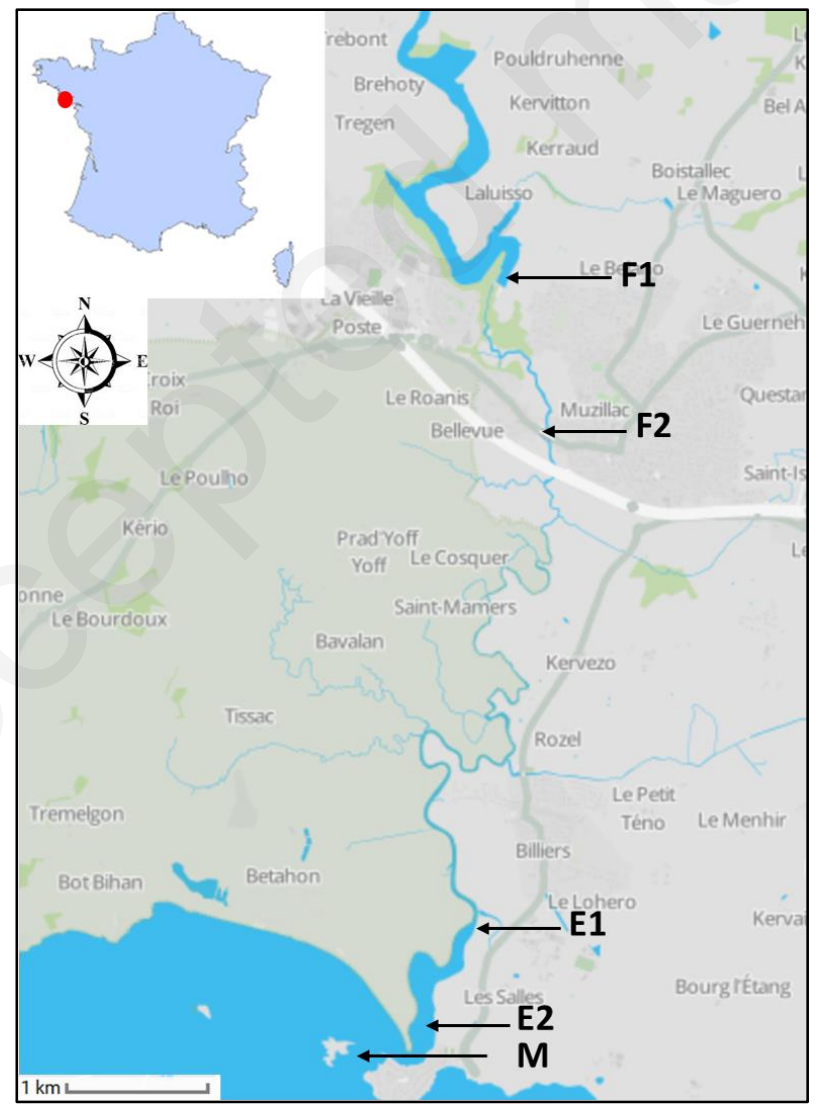

125 Fig. 1: Map of the study site and sampling stations: F1 and F2 are located in the 126 freshwater section, E1 and E2 in the estuarine section and $M$ at the marine outlet. 
128 At each station, subsurface grab water sampling was carried out in the water column

129 to: i) determine physico-chemical parameters (temperature, conductivity, dissolved 130 oxygen, Phosphorus and Nitrogen) using a YSI 6920 multi-parameter probe (YSI 131 Environmental, Anhydre) and physico-chemical analyses, ii) describe phytoplankton 132 and cyanobacterial species (identification and enumeration), and (iii) quantify 133 microcystins in the phytoplanktonic biomass and in the filtered water. At each station, 134 surface sediment sampling (top 1 to $2 \mathrm{~cm}$ ) was carried out to (i) determine sediment 135 characteristics including percentage of organic matter (OM) and major elements, ii) 136 identify and count phytoplankton species including cyanobacteria, (iii) quantify 137 cyanotoxins and (iv) determine the presence of $\mathrm{MC}$ and anatoxin production genes. It 138 is important to note that for the sampling of surface sediment, the site F1 was chosen 139 in the river directly downstream of the reservoir, as no sediment was found in the 140 reservoir itself at the site where the water column sampling was performed, the 141 bottom there being dominated by larger rocks.

142

143

144

145

146

147

148

149

150

151

152

153

154

155

156

\subsection{Samples Analyses}

\subsubsection{Water analyses}

Water column samples were transported in dark and cold conditions and filtered upon arrival at the laboratory within few hours of sampling. Dissolved inorganic nutrient concentrations were measured from filtered (GF/F $0.7 \mu \mathrm{m}$ ) water using common colorimetric methods with a Bran and Luebbe Autoanalyser 3 (Axflow, Norderstedt, Germany). Nitrate was measured after reduction to nitrite on a cadmium-copper column (Henriksen and Selmer-Olsen 1970). Phosphate was measured following the method of Murphy and Riley (1962). Filtration was also done to determine total suspended solids (TSS). Whatman glass fiber filters (GF/F $0.7 \mu \mathrm{m}$ ) were dried at $105^{\circ} \mathrm{C}$ and weighed. Ashing to $550^{\circ} \mathrm{C}$ was performed to determine the organic contribution. Phytoplankton and cyanobacteria identification and counts were conducted on both fresh and lugolised samples under an optical microscope (100x magnification) using a Nageotte chamber within 48 hours of sampling as reported in Lance et al. (2010) and Pannard et al. (2018). This was preferred over a haemocytometer chamber for the larger volume sampled to limit counting errors as described in Brient et al. (2008). 
165 Water samples containing cyanobacteria were filtered upon arrival at the laboratory through a $0.1 \mu \mathrm{m}$ GF filter to separate the cell pellet for the intracellular cyanotoxin analysis and the filtrate which may contain dissolved extracellular toxins. Both filters and filtrates were frozen at $-20^{\circ} \mathrm{C}$ until chemical analysis. The filtrate was purified on a $\mathrm{C}_{18}$ SPE cartridge (Solid Phase Extraction) according to the ISO 20179 standard method (Anon, 2005). The fraction containing the toxins was frozen until LC-MS/MS analysis. The GF filter was sonicated with $10 \mathrm{~mL}$ of $\mathrm{MeOH}$ for 15 minutes. The $\mathrm{MeOH}$ extract was evaporated under nitrogen and then the residue was diluted in 1.5 $\mathrm{mL}$ of methanol.

\subsubsection{Sediment samples}

Fresh surface sediment was kept in the dark and at $4^{\circ} \mathrm{C}$ until analyses. Sediment characteristics including major elements and \% organic matter (OM) were analysed by the SARM (Service d'Analyse des Roches et des Minéraux) laboratory (Nancy, France) using an ICP-MS iCapQ instrument.

\subsubsection{Extraction of cyanobacteria}

184 Cyanobacteria were extracted from sediment using a density gradient with Ludox 185 TM-50 (Sigma-Aldrich, Saint Louis, USA), as described in Legrand et al. (2016). 0.5g 186 of fresh sediment was diluted with $9.5 \mathrm{ml}$ of distilled water and $4 \mathrm{ml}$ of Ludox. These solutions were sonicated for 30 seconds with a frequency of $50 \%$ and a power of 80 W (Sonoplus, Bandelin, Berlin, Germany). Finally, solutions were centrifuged at $10,000 \times \mathrm{g}$ for 30 minutes and after the first $6 \mathrm{ml}$ was pipetted and kept in the dark at $4^{\circ} \mathrm{C}$ for further analysis.

\subsubsection{Estimation of cyanobacterial abundance}

193 Genus determination for vegetative cells and akinetes (Nostocale resting stage cells) was based on morphological criteria using reference books (Bourelly 1985; Komàrek and Anagnostidis 2005, 2013). $2 \mathrm{ml}$ of Ludox solution was filtered through an 8- $\mu \mathrm{m}$

196 mesh (TETP filter; Merck Millipore, Tullagreen, Ireland). Counts were performed in

197 triplicate for each sample in this study. Cyanobacteria were enumerated at a 
198 magnification of x200 with an epifluorescence microscope (Axiovert $200 \mathrm{M}$; Zeiss,

199 Oberkochen, Germany) and a minimum of 40 fields was counted for each filter. One sample (F2) was tested for cell viability with SYTOX green following Legrand et al. 201 (2016). Briefly, $1 \mu \mathrm{L}$ of SYTOX green $(50 \mathrm{mM})$ was added for $1 \mathrm{~mL}$ of isolated 202 cyanobacterial solution. Resulting solution was incubated in the dark at least for 30 $203 \mathrm{~min} .1 \mathrm{~mL}$ of this solution was filtered using an $8 \mu \mathrm{m}$ filter (TETP, Merck Millipore, 204 Tullagreen, Ireland). The sample was enumerated with the same epifluorescence 205 microscope than previously. Two separate counts were performed: the first at 546 $206 \mathrm{~nm}$ to determine intact cells sill containing chlorophyll pigment; and the second at $448 \mathrm{~nm}$ to discriminate damaged cells with SYTOX green staining.

\subsubsection{DNA extraction and target genes amplification}

210 Genomic DNA from sediment samples was extracted with the FastDNA® Spin kit for 211 soil (MP biomedicals, Santa Ana, USA) following the manufacturer's instructions. The 212 DNA concentration in each sample was estimated using a UV spectrophotometer 213 (Nanodrop® ND 2000). The cyanobacterial 16S rRNA gene was amplified in 214 sediment samples using the cya359F and cya781R set of primers from Nubel et al. 215 (1997). Then, two genes involved in the biosynthesis of microcystin, mcy $A$ and mcy $B$ 216 genes and one gene involved in the biosynthesis of anatoxin-a, anaC, were also 217 investigated in this study, given the cyanobacterial species found in sediment. anaC 218 and mcyB were amplified with nested PCRs whereas classic PCR was used to detect 219 mcyA. For mcyB nested PCR, MCY F1/R1 then MCY F1/R2 were used and mcyA_Cd1F and mcyA-Cd1R for mcyA. anaC was detected with the sets of primers anxgen-F2/R and anaC 80F/706R for nested 1 and 2 PCR respectively. All PCR mixtures and PCR programs were the same as described in Legrand et al. (2017). All

223 PCR products were revealed with $0.5 \%$ agarose gel with $0.3 \mathrm{mg} \mathrm{L}^{-1}$ ethidium bromide 224 and migrated in a TAE buffer $0.5 \mathrm{X}$ at $100 \mathrm{~V}$ for 30 minutes.

\subsubsection{Microcystin extraction}

227 To analyse total MC (intracellular plus extracellular), the crude sediment 228 (approximately $2 \mathrm{~g}$ ) were extracted, according to the method of Umehara et al 229 (2012), 4 times with $4 \mathrm{ml}$ of $\mathrm{MeOH} / \mathrm{H}_{2} \mathrm{O}(30 \% / 70 \%)$, each time using sonication for 45 $230 \mathrm{~min}$ and then centrifugation at $3500 \mathrm{~g}$ at $4{ }^{\circ} \mathrm{C}$ for $10 \mathrm{~min}$. To analyse intracellular 
231 MC, the ludox supernatant containing cyanobacteria was filtered under pressure

232 (around 53kPA) using $25 \mu \mathrm{m}$ nylon filtration tissues in order to eliminate akinetes and 233 extracellular MC. These tissues were cleaned with distilled water under pressure 3 234 times. Then, tissues containing Microcystis were cleaned with methanol 100\%. 235 These solutions were kept in dark conditions at $4^{\circ} \mathrm{C}$ until further analysis.

\subsubsection{Chemical analysis of microcystins by LC-MS / MS}

241 through a $0.2 \mu \mathrm{m}$ filter and analyzed by Ultra Fast Liquid Chromatography 242 (Shimadzu, Marne la Vallée, France) coupled to API-5500 QTrap tandem mass 243 spectrometry (ABSciex, Villebon sur Yvette, France). Toxins were separated on a 244 Kinetex XB C18 column (100 x $2.1 \mathrm{~mm}, 2.6 \mu \mathrm{m}$, Phenomenex) at $25^{\circ} \mathrm{C}$, with water 245 (A) and acetonitrile (B), both containing $0.1 \%$ formic acid at $0.3 \mathrm{~mL} \mathrm{~min}^{-1}$ flow rate. 246 The gradient was raised from 30 to $80 \%$ B in 5 min and was held during 1 min before dropping down during $0.5 \mathrm{~min}$ to the initial conditions.

Mass spectrometry detection was carried out in multiple reactions monitoring (MRM) mode. The electrospray ionization interface (ESI) was operated in positive mode using source setting: curtain gas set at 30 psi, ion spray at $5000 \mathrm{~V}$, a turbogas temperature of $300^{\circ} \mathrm{C}$, gas 1 and 2 set at 30 and 40 psi respectively and an entrance potential of $10 \mathrm{~V}$. Each toxin was identified and quantified with two transitions as

254 follow (Table S1): The toxin concentrations were determined using certified standards provided by CNRC (Halifax, NS, Canada). The method was developed and validated internally in the IFREMER Phycotoxins laboratory.

Table S1: LC-MS/MS transitions for the 9 MC variants tested with standards

\begin{tabular}{|cccc|}
\hline Toxin & Precursor ion $(\mathrm{m} / \mathrm{z})$ & $\begin{array}{c}\text { Transition }(\mathrm{m} / \mathrm{z})- \\
\text { Quantification }\end{array}$ & $\begin{array}{c}\text { Transition }(\mathrm{m} / \mathrm{z}) \text { - } \\
\text { identification }\end{array}$ \\
\hline MC-LR & 995.6 & 213.2 & 374.5 \\
\hline MC-LW & 1025.6 & 375.2 & 135.2 \\
\hline MC-LF & 986.6 & 375.2 & 135.2 \\
\hline
\end{tabular}




\begin{tabular}{|cccc|}
\hline MC-LY & 1002.6 & 375.2 & 135.2 \\
\hline dmMC-LR & 981.4 & 103.0 & 135.2 \\
\hline MC-RR & 520.1 & 135.2 & 213.2 \\
\hline dmMC-RR & 512.8 & 135.0 & 103.0 \\
\hline MC-LA & 910.7 & 375.2 & 135.2 \\
\hline MC-YR & 1045.6 & 213.2 & 375.2 \\
\hline
\end{tabular}

\section{Results}

\subsection{In the water column}

\subsubsection{Physico-chemical parameters}

The physico-chemical characteristics of the water sampled at each site along the continuum are presented in Table 1. While temperature was constant along the continuum, conductivity (as a proxy of salinity) increased from upstream to downstream. Dissolved oxygen exhibited a decreasing concentration associated with a simultaneous decrease in $\mathrm{Chl}$ a concentration. Nitrate presented an upstream to downstream decrease while phosphate values showed the opposing trend with higher values downstream. The total suspended solids in the water column exhibited higher concentrations downstream in the estuary and revealed a decreasing gradient in percentage of organic matter (OM) varying from $100 \%$ in freshwater to $24 \%$ at the 277 marine site.

Table 1 : Physico-chemical parameters measured in the water at the 5 sampling stations

\begin{tabular}{cccccccccc}
\hline Sites & $\begin{array}{c}\text { Temp } \\
\left({ }^{\circ} \mathbf{C}\right)\end{array}$ & $\begin{array}{c}\text { Cond } \\
(\mathbf{m S} / \mathbf{c m})\end{array}$ & $\begin{array}{c}\mathbf{O}_{2} \\
(\mathbf{m g} / \mathbf{L})\end{array}$ & $\begin{array}{c}\text { Chl a } \\
(\mu \mathrm{g} / \mathrm{L})\end{array}$ & $\mathbf{p H}$ & $\begin{array}{c}\mathbf{P}^{-P O} \mathbf{H}_{4} \\
(\mathbf{m g} / \mathbf{L})\end{array}$ & $\begin{array}{c}\mathbf{N}-N_{3} \\
(\mathbf{m g} / \mathbf{L})\end{array}$ & $\begin{array}{c}\text { TSS } \\
(\mathbf{m g} / \mathbf{L})\end{array}$ & $\begin{array}{c}\text { OM } \\
(\%)\end{array}$ \\
\hline F1 & 14.80 & 0.24 & 13.67 & 22.70 & 8.02 & 0.070 & 1.51 & 34 & 100.0 \\
F2 & 14.52 & 0.26 & 10.91 & 13.54 & 7.59 & 0.017 & 1.17 & 25 & 85.3 \\
E1 & 14.93 & 12.30 & 9.61 & 6.29 & 7.54 & 0.044 & 0.98 & 121 & 35.9 \\
E2 & 14.98 & 45.35 & 8.63 & 0.07 & 7.78 & 0.042 & 0.47 & 148 & 30.5 \\
M & 14.96 & 40.21 & 7.84 & 1.06 & 7.77 & 0.055 & 0.48 & 135 & 24.7 \\
\hline
\end{tabular}

\subsubsection{Phytoplankton/Cyanobacteria community}


285 In the water column, the phytoplankton community was largely dominated by 286 cyanobacteria in cells density (Fig. 2). In particular several species of the Microcystis genus (M. aeruginosa, M. botrys, $M$. viridis and $M$. flos-aquae) accounted for most of 288 the cells density at the freshwater sites. M. aeruginosa was the only cyanobacterial species observed in the estuary with a concentration of $3.7 \times 10^{4}$ cells $\mathrm{mL}^{-1}$ at E1.

290 Several Chlorophyceae and pennate diatoms were also recorded in the estuary in 291 low numbers $\left(<10^{3}\right.$ cells $\left.\mathrm{mL}^{-1}\right)$.

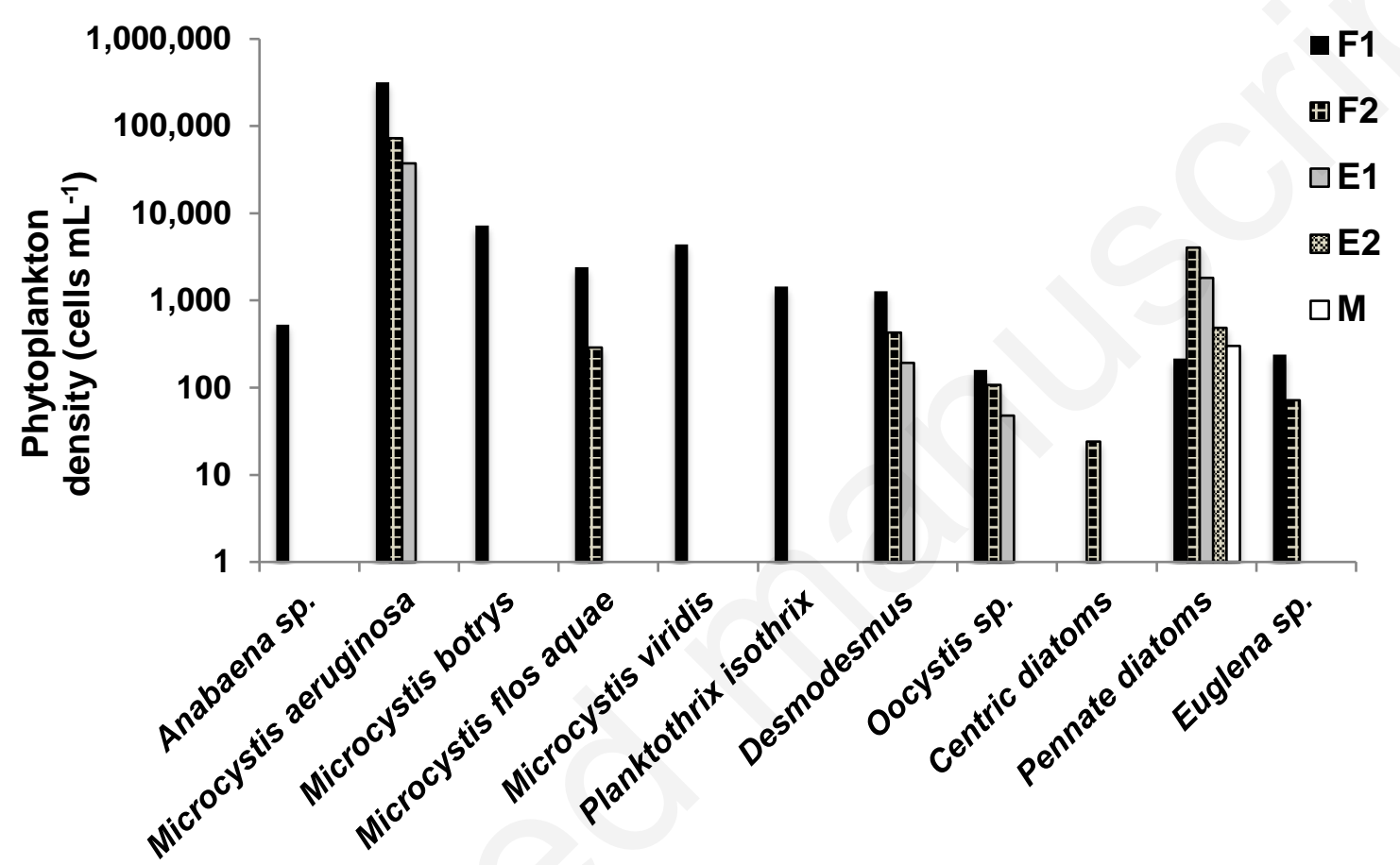

Fig 2: Species composition and phytoplankton density in the water column at the 5 stations along the freshwater-marine continuum on October 10, 2018

297 The biovolumes of the phytoplankton groups present together with the percentage of cyanobacteria in the total biovolume of phytoplankton at each site are presented in

299 Table 2, demonstrating the strong dominance of cyanobacteria at the three most 300 upstream sites.

Table 2 : Biovolume of phytoplankton groups at each sampling site

303

\begin{tabular}{|c|c|c|c|c|c|}
\hline Biovolume $\left(\mathrm{mm}^{3} \mathrm{~L}^{-1}\right)$ & F1 & F2 & E1 & E2 & $\mathbf{M}$ \\
\hline Cyanobacteria & 21.655 & 4.721 & 2.434 & 0.000 & 0.000 \\
\hline Chlorophyceae & 0.079 & 0.035 & 0.037 & 0.000 & 0.000 \\
\hline Bacillariophyceae & 0.061 & 1.147 & 0.258 & 0.008 & 0.005 \\
\hline
\end{tabular}


304

305

306

307

308

309

310

311

312

313

314

315

316

Euglenophyceae

0.201

0.060

0.000

0.000

0.000

\% Cyanobacteria

0.984

0.792

0.892

0.000

0.000

\subsubsection{Intracellular and extracellular microcystins}

We observed a gradual decrease of intracellular MC along the continuum from 28 $\mu \mathrm{g} / \mathrm{L}$ in the freshwater reservoir, $3 \mu \mathrm{g} \mathrm{L}^{-1}$ in the estuary and down to $0.21 \mu \mathrm{g} \mathrm{L}^{-1}$ at the marine station (Fig. 3A). This gradual decrease was mostly associated with the decrease in cyanobacterial biovolume, in particular that of $M$. aeruginosa. Indeed, based on $M$. aeruginosa densities, the cellular quotas corresponded to $88 \mathrm{fg} \mathrm{cell}^{-1}$ at $\mathrm{F} 1,69 \mathrm{fg} \mathrm{cell}^{-1}$ at F2 and $80 \mathrm{fg} \mathrm{cell}^{-1}$ at E1. Nine MC variants were recorded with the dominance of MC-LR followed by MC-RR and MC-YR among all sites. No particular selection of variants was observed with increasing salinity.

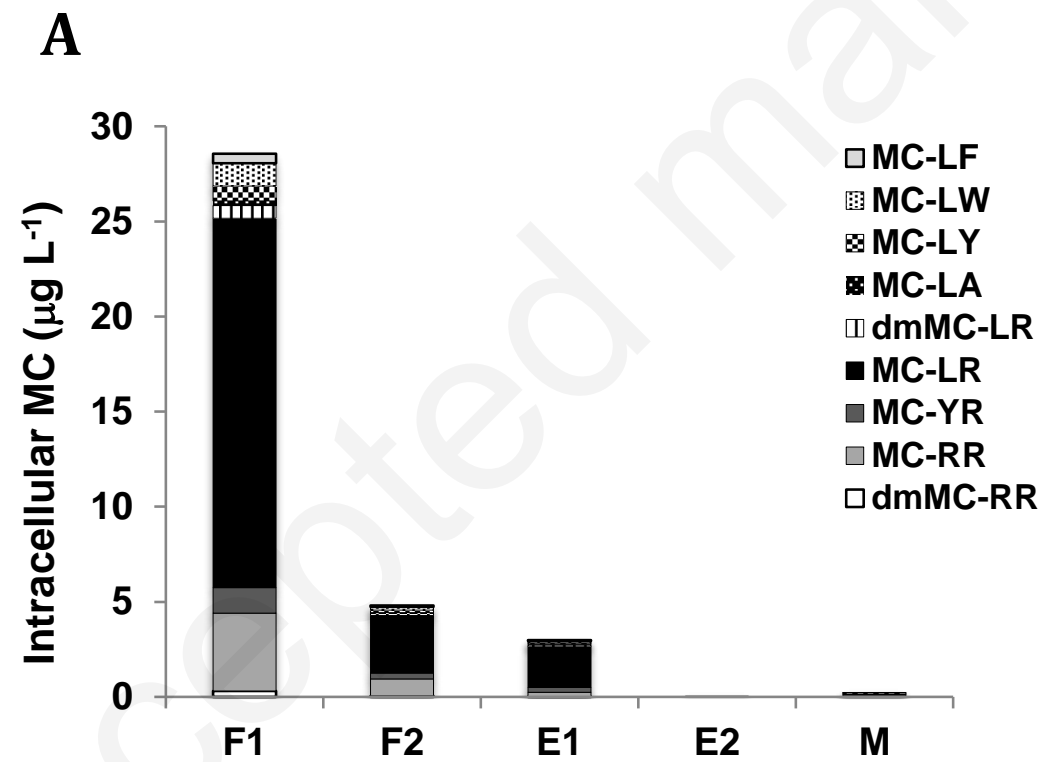

A

Fig 3A) Intracellular MC present in the cyanobacterial biomass in the water at the investigated sites

The extracellular MC measured in the filtrate was much smaller (100 to 400 times) than the intracellular fraction, varying between 0.1 and $0.3 \mu \mathrm{L} \mathrm{L}^{-1}$, but increased from upstream to downstream (Fig. 3B). In particular, at the two most downstream sites, the proportion of extracellular/total MC reached $90 \%$ and $55 \%$ respectively. 


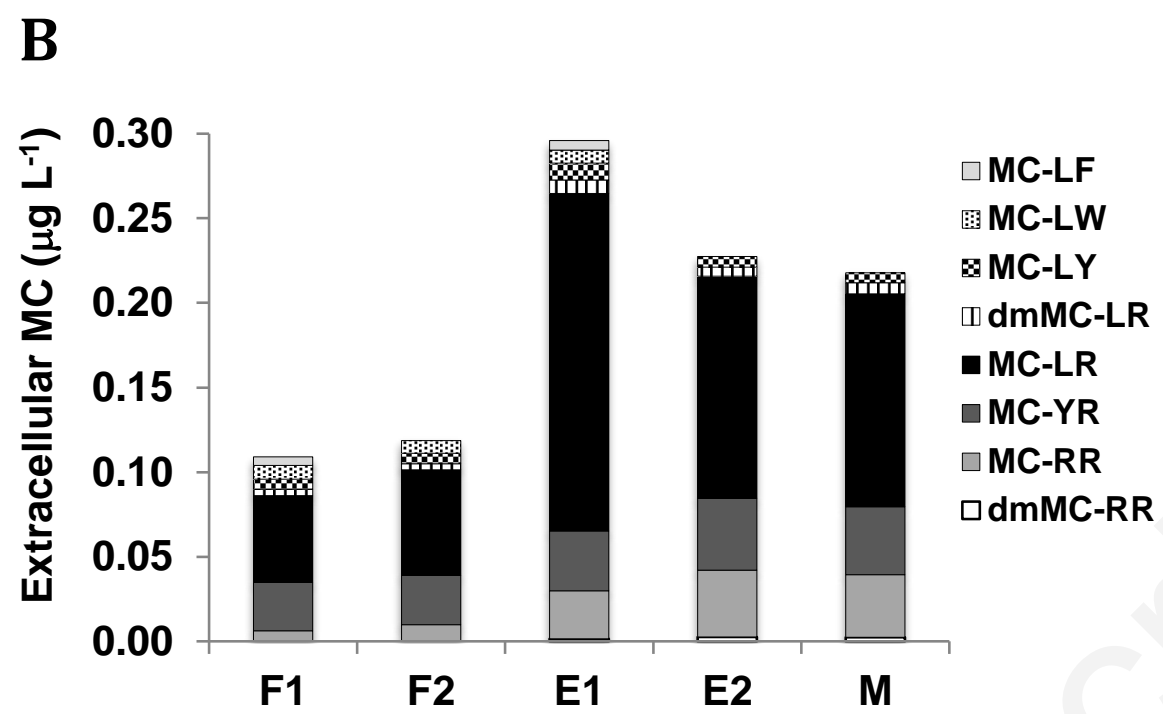

Fig. 3B) Extracellular MC present in dissolved form in the water

Similarly to the intracellular fraction, $9 \mathrm{MC}$ variants were recorded in the extracellular fraction and the dominant MC variant was MC-LR. It was followed by MC-YR and MC-RR at low salinities while MC-RR became more abundant at higher salinities.

\subsection{In surface sediments}

\subsubsection{Chemical characteristics}

Overall, the surface sediment characteristics were not drastically different along the estuary (Table 3). Surface sediment showed a dominance of inorganic material at all 5 sites with a maximum of $17 \%$ of organic matter $(\mathrm{OM})$ at the marine site. They contained a high proportion of silicate $\left(\mathrm{SiO}_{2}\right)$ (50 to $73 \%$ ), aluminum $\left(\mathrm{Al}_{2} \mathrm{O}_{3}\right)$ (up to $15 \%$ ), calcium ( $\mathrm{CaO}$ ) (up to $9.8 \%$ ), iron $\left(\mathrm{Fe}_{2} \mathrm{O}_{3}\right)$ (up to $6.7 \%$ ), potassium $\left(\mathrm{K}_{2} \mathrm{O}\right)$ and sodium ( $\mathrm{Na}_{2} \mathrm{O}$ ) (up to $4 \%$ ), magnesium ( $\mathrm{MgO}$ ) (up to $2.3 \%$ ) and phosphorus $\left(\mathrm{P}_{2} \mathrm{O}_{5}\right)$ (up to $0.3 \%$ ). The $\mathrm{OM}$ was maximal at F2 and $\mathrm{M}$ where sediment was fine and muddy while sediment at F1 and E2 was coarser and sandy. The water content of sediment varied between 30 and $71 \%$ being higher in muddy sediment. Coarser sandy sediment was also lower in $\mathrm{Fe}, \mathrm{Mn}, \mathrm{Mg}$ and $\mathrm{OM}$. 
Table 3 : Surface sediment characteristics along the continuum

\subsubsection{Cyanobacteria biomass}

There was a dominance of Microcystis sp. (> 90\%) with some akinetes of Dolichospermum sp, (Komàrek 2016) and few filaments of Planktothrix sp. at F2 in surface sediment. The presence of Microcystis cells in surface sediment was recorded at all 5 sites with concentrations varying between $3 \times 10^{3}$ and $3 \times 10^{6}$ cells $\mathrm{g}^{-1}$ dry weight (DW) of sediment (Fig 4).

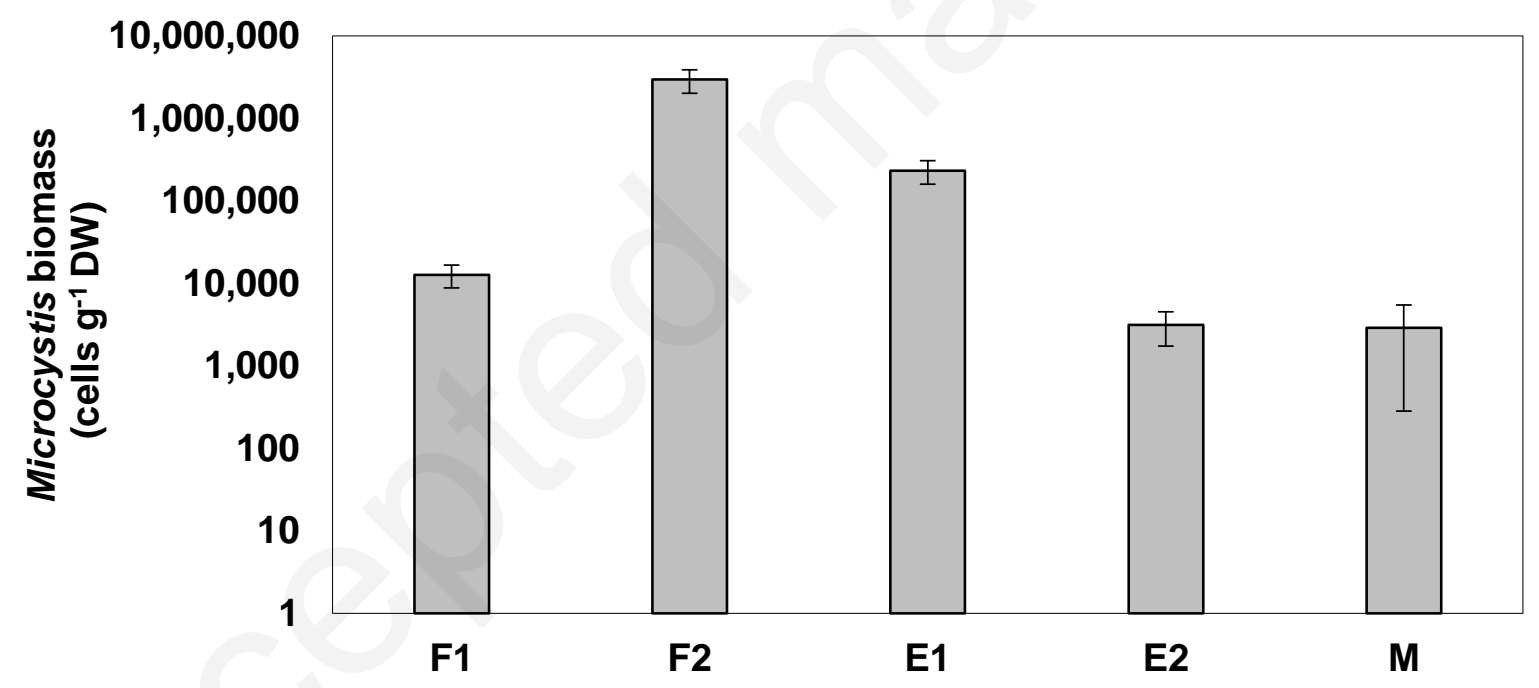

Fig 4: Microcystis biomass in surface sediment at the 5 sampling sites along the continuum.

Photographs from epifluorescence microscopy together with counting suggested that 373 the cells were not lysed (Fig. 5). 

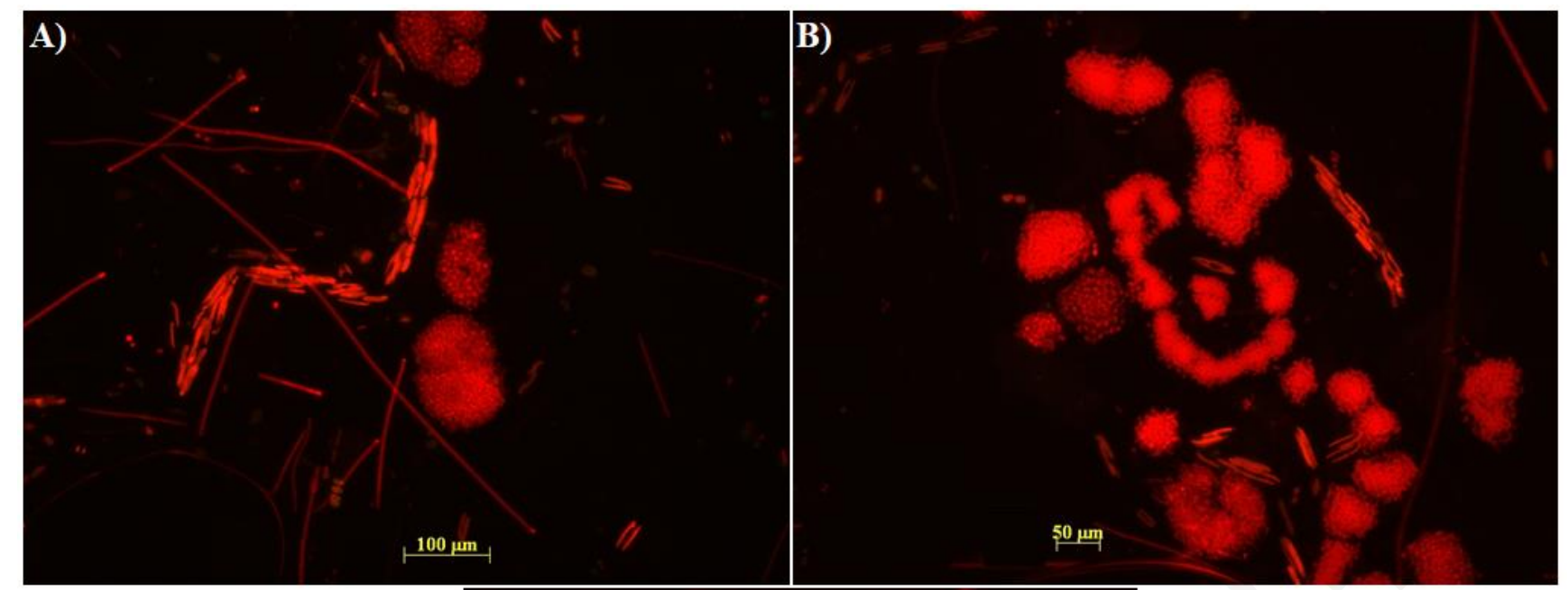

\section{C)}

Fig 5: Photomicrographs of extracted Microcystis from studied sediment (Epifluorescence light): colonies with filaments and diatoms (x100), focus on colony (x200), focus on Microcystis intact cells (x400)

\subsubsection{Intracellular and extracellular microcystins}

Intracellular MC varied between $193 \mu \mathrm{g} \mathrm{kg}^{-1}$ wet weight (WW) at F2, $14.4 \mathrm{mg} \mathrm{kg}^{-1} \mathrm{WW}$ of sediment at E1, $0.2 \mu \mathrm{g} \mathrm{kg}^{-1} \mathrm{WW}$ at $\mathrm{E} 2$ and non detectable at site $\mathrm{M}$ (Fig. 6A). These intracellular concentrations corresponded respectively to $482 \mathrm{\mu g} \mathrm{kg}^{-1} \mathrm{DW}$ at F2, $36 \mu \mathrm{g} \mathrm{kg}^{-1} \mathrm{DW}$ at E1 and $0.5 \mu \mathrm{g} \mathrm{kg}^{-1} \mathrm{DW}$ at E2. The quantification of intracellular $\mathrm{MC}$ in the estuarine sediment indicates that cells of $M$. aeruginosa were not lysed and that sediment preserved at least some cells intact. Different $M C$ variants were recorded in the sediments with the dominance of MC-LR, RR and YR similarly to the proportions observed in the water column. 
400

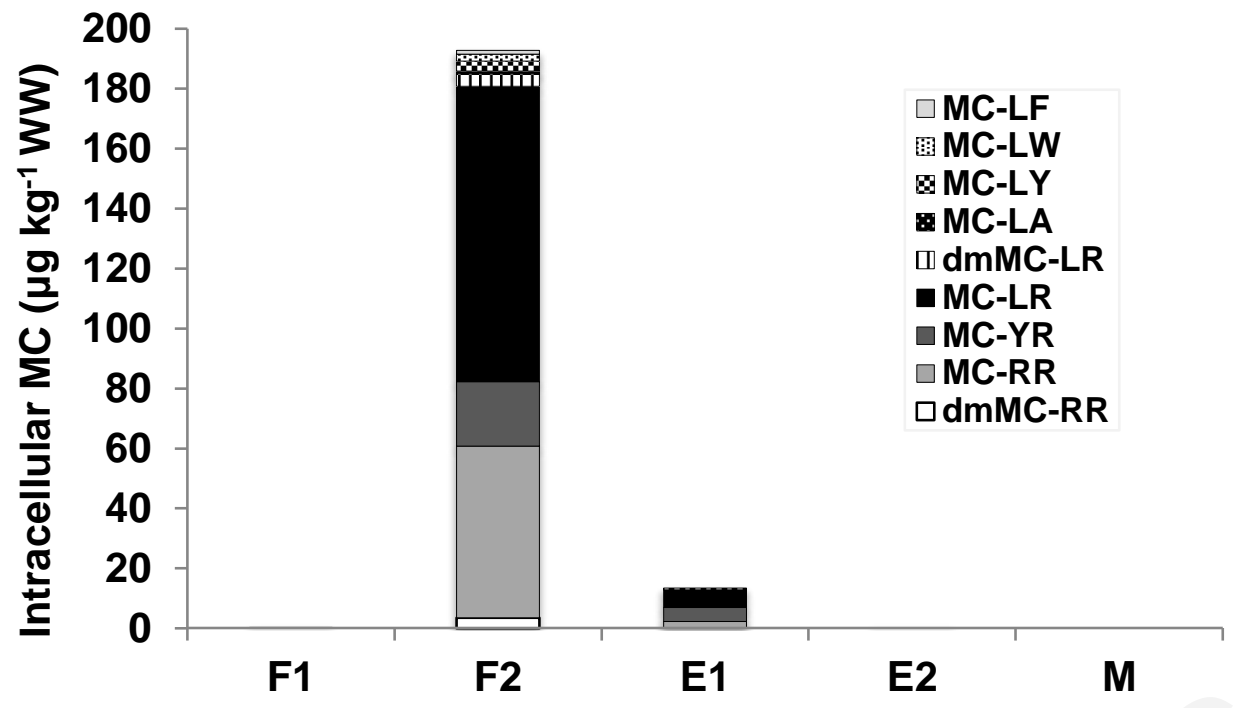

Fig 6A: Intracellular MC in surface sediment along the continuum

Extracellular MC concentrations were inferred from subtracting the intracellular concentrations from the total MC. Extracellular MC in surface sediment varied also along the estuary between $733 \mu \mathrm{gg}^{-1} \mathrm{WW}$ at F2 (1832 $\left.\mathrm{gg} \mathrm{kg}^{-1} \mathrm{DW}\right), 70 \mu \mathrm{g} \mathrm{kg}^{-1} \mathrm{WW}$ at $\mathrm{E} 1$ (175 $\mu \mathrm{g} \mathrm{kg}^{-1} \mathrm{DW}$ ) and non detectable further downstream (Fig. 6B).

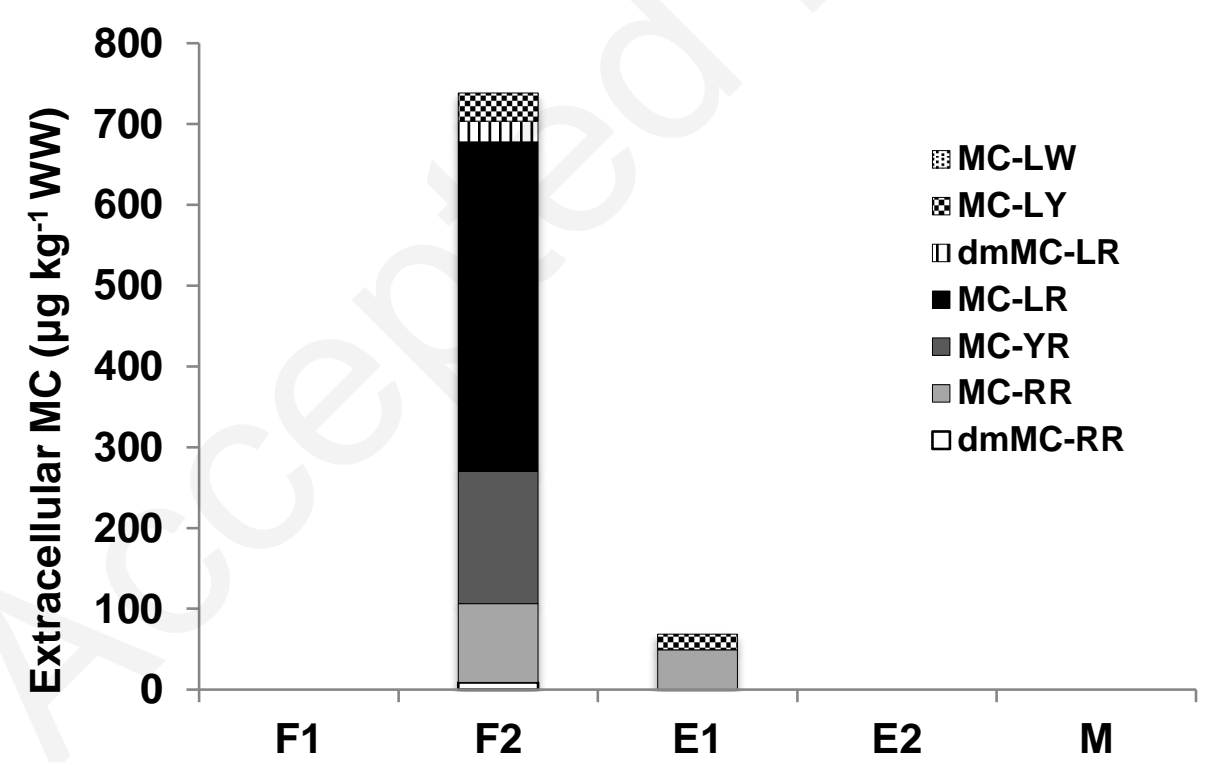

Fig 6B: Extracellular MC in surface sediment along the continuum 


\subsubsection{Genes presence}

Table 4: Detection of the targeted genes in studied surface sediments

\begin{tabular}{ccccc}
\hline & $\begin{array}{c}\text { Cyanobacterial } \\
\text { 16S rRNA gene }\end{array}$ & mcyA & mcyB & anaC \\
\hline PCR & Classic & Classic & Nested & Nested \\
\hline F1 & + & + & + & - \\
F2 & + & + & + & + \\
E1 & + & + & + & - \\
E2 & + & + & + & - \\
M & + & - & + & - \\
\hline
\end{tabular}

414

The PCR analyses using both classic and nested approaches confirmed the presence of cyanobacterial species in sediment at all sites. Microcystin genotypes were omnipresent. Indeed, microcystin biosynthesis genes were detected in the sediment of all studied sites except mcyA at the most downstream station (Table 4). In the freshwater section at F2, the anaC gene was also detected suggesting the presence of species potentially producing anatoxin. This site exhibited the highest cyanobacterial biomass including akinetes of Dolichospermum $s p$. and long filaments of Planktothrix sp. (data not shown).

\section{Discussion}

This is the first study reporting on co-occurrence of both cyanobacteria and $\mathrm{MC}$ in estuarine/marine waters and sediments, resulting from a freshwater discharge of an upstream reservoir. Moreover we report separately the quantification of intracellular and extracellular forms of MC.

\subsection{In the water column}

Cyanobacteria dominated the phytoplankton community in the water column with high densities and biovolumes at the freshwater sites and decreasing concentrations along the salinity gradient. Temperatures during sampling around $15^{\circ} \mathrm{C}$ at all 5 sites were much lower than the growth optimal temperature of cyanobacteria in general 
and of Microcystis in particular (Carey et al. 2012) but still within growth potential

438 observed in freshwater lakes and reservoirs (Kruk et al. 2017). Spatial variation of 439 cyanobacterial biomass was most likely due to salinity as nutrients were unlikely to 440 limit cyanobacterial growth (Reynolds 2006). Nitrate showed an upstream to 441 downstream decrease suggesting a freshwater dominant source consistent with high 442 nitrate from agricultural lands in the upstream catchment (Le Moal et al. 2019). 443 Phosphate values showed the opposing trend with higher values downstream in the 444 estuary where we expect sediment resuspension to be the largest, based on the 445 observed high concentrations of total suspended solids and high tidal energy flows. 446 Although the freshwater discharge was not monitored and therefore not quantified, 447 the progressive increase in salinity near the surface was a good indicator of dilution. 448 The short residence time (of the order of one day), inferred from observations of the 449 surface velocities during sampling, would not permit in situ growth. Hence we 450 suggest that the lower biomass in the estuary results from freshwater discharge 451 dilution with estuarine water even though we minimized that influence by sampling 452 within one hour of low tides.

454 The dominant blooming genus in the upstream freshwater reservoir was 455 overwelmingly Microcystis, consistent with the most widespread cyanobacterial 456 occurrence of Microcystis in freshwaters worldwide (Harke et al. 2016) and indeed in 457 Brittany (Pitois et al. 2014). While several species of Microcystis co-occurred at the 458 two freshwater sites, $M$. aeruginosa was the only species found in the estuary. This 459 observation is in accordance with several other studies worldwide which report on $M$. 460 aeruginosa as the dominant species in estuaries (Preece et al. 2017) in relation with 461 its highest salinity tolerance among cyanobacteria (Verspagen et al. 2006). 462 Conductivities in the estuary and at the marine outlet ranged during sampling from 12 463 to $45 \mathrm{mS} \mathrm{cm}^{-1}$ corresponding to salinities from 7 to 27 , the maximum value beyond 464 reported values for $M$. aeruginosa salinity tolerance (Verspagen et al. 2006) and 465 justifying that no $M$. aeruginosa cells were found in the water column at the two most 466 downstream stations. The mechanisms of salinity tolerance in $M$. aeruginosa are still 467 unclear and current hypotheses include the presence of sucrose genes acting as 468 osmolytes (Tanabe et al. 2018) or the role of mucilage protection against osmotic 469 shock (Kruk et al. 2017). 
M. aeruginosa density was high in the estuarine section (at E1) at intermediate salinity reaching $3.7 \times 10^{4}$ cells $\mathrm{mL}^{-1}$ and associated with intracellular $\mathrm{MC}$ of $3 \mathrm{\mu g} \mathrm{L}^{-1}$, resulting in a $M C$ quota of $80 \mathrm{fg} \mathrm{cell}^{-1}$, if we assume that $M C$ was only due to $M$. aeruginosa cells and that all $\mathrm{M}$. aeruginosa cells were toxic. This quota is similar to that measured in freshwater at F1 and F2, suggesting no particular change with salinity. Very few studies report on MC quotas in natural environments especially in estuaries. Moreover according to Wood et al 2011, MC quotas in situ can vary by 20 fold in 5 hours, and potentially are the response to a potential stress.

The toxins profiles in the cyanobacterial biomass (intracellular form) and dissolved in the water (extracellular form) were dominated by MC-LR, RR and YR similarly to those of a previous study when Microcystis was the dominant genus at the same sites (Bormans et al. 2019). Both intracellular and extracellular MC exhibited here higher concentrations than previously reported in the literature. The downstream gradient of intracellular MC was consistent with the downstream gradient in Microcystis biovolume in the water column while extracellular MC showed a reverse trend and increased at higher salinities suggesting some cells lysing. In accordance with literature results the dominant form of $\mathrm{MC}$ in the freshwater part was intracellular (Orr and Jones 1998; Briand et al. 2012), while the dominant form became extracellular as cells lysis increased at elevated salinity (Tonk et al. 2007; Bormans et al. 2019). Both intracellular and extracellular toxins were measured in the water (at E2 and M) while cyanobacterial cells were not counted at those sites. This result confirms previous reports that toxins can persist as extracellular form in the water after the presence of cyanobacteria (Briand et al. 2009). Concerning the presence of intracellular MCs in the water column, cyanobacterial cells may have been too scarce at the marine site to be visualised. Bukaveckas et al. 2018 also reported MC concentrations in the water column at the river estuarine interface of the James River while no cyanobacterial cells were recorded. However their values of total MC were very low $\left(<0.3 \mu \mathrm{g} \mathrm{L}^{-1}\right)$ and only measureable in the freshwater section (salinity $\left.<0.5\right)$. While Umehara et al. (2015) reported in Isahaya Bay total MC values of $0.06 \mu \mathrm{g} \mathrm{L}^{-1}$ at salinities approaching 30, we found a much higher concentration with total $\mathrm{MC}=$ $0.4 \mu \mathrm{g} \mathrm{L}^{-1}$, most likely due to the high toxin concentration in the upstream reservoir. 


\subsection{In surface sediments}

Most bottom sediments that accumulate in the estuarine zone consist of terrestrial detritus and biogenic debris. The surface sediments were dominated by inorganic material with a high proportion of silicate, which can have both a riverine and marine origin, if associated with biogenic production by diatoms (Conley 1997; Maavara et al. 2014). The organic matter percentage was maximum at $F 2$ and $M$ where the sediments were fine and muddy while sediments at F1 and E2 were coarse and sandy. Coarser sandy sediments were also lower in Fe, Mn, Mg and $\mathrm{OM}$ as is often found in estuaries (Folger 1972).

Quantifying cyanobacterial cells in sediments is difficult as reported by Pham and Utsumi (2018). The presence of Microcystis was observed in surface sediments at all 5 sites along the freshwater marine continuum in relatively high densities even at the marine outlet. Microcystis abundance was the highest at F2 where Microcystis concentration reached $3 \times 10^{6}$ cells $\mathrm{g}^{-1}$ DW of sediment corresponding to bloom concentrations. The higher number of cells at F2 compared to F1 is not surprising given that the sediment sampling at $F 1$ was done in the flowing river downstream of the reservoir, while F2 corresponded to a much more stagnant water, associated with muddy sediments rich in OM. Hence F2 acted as a sediment trap accumulating Microcystis cells. The presence of Microcystis in sediments is consistent with Microcystis being the dominant species being transferred in the water column from the upstream reservoir freshwater discharge. Moreover, Microcystis concentration gradient in surface sediments along the salinity gradient reflected Microcystis concentration gradient in the water column over several months to years (Bormans et al. 2019) rather than instantaneously (this study).

Microcystis cells in the sediments were found intact and in high numbers suggesting a preservation role of sediments even at high salinities. The exact quantification of abundance of colonial cells is always a challenge. The presence of colonies in the sediments indicated that the mucilage was probably preserving cells from lysing (Misson et al 2012; Xiao et al. 2018) and that these cells had been deposited in the sediments during freshwater discharge (Kruk et al. 2017). At the two most downstream sites where no Microcystis cells were found in the water column due to high salinities, some Microcystis colonies were still intact in the sediments. While the 
filtration at $8 \mu \mathrm{m}$ did not allow the observation of individual Microcystis cells, it is very

539 unlikely that cells without the protection of the mucilage would survive degradation 540 and salinity osmotic shock as demonstrated for unicellular M. aeruginosa (Georges 541 des Aulnois et al. 2019). Cyanobacterial cells can survive in sediments depending on 542 numerous factors such as river flow, depth, bathymetry, sediment composition or 543 redox conditions (Kravchuk et al. 2011; Legrand et al. 2017; Grutzmacher et al. 544 2010). Hence, some Microcystis cells can be punctually released in the estuary 545 explaining the decreasing gradient from the beginning of the estuary to the marine 546 section. These phenomena of primary and secondary sedimentation have already 547 highlighted in lacustrine ecosystems (Evans 1994; Verspagen et al. 2005; Cirés et al. 548 2013; Legrand et al. 2017).

550 Concentrations of both extracellular and intracellular toxins measured in the 551 sediments were relatively high compared to literature values. We measured total MC 552 concentrations of $926 \mu \mathrm{g} / \mathrm{kg} \mathrm{WW}$ (or $2315 \mu \mathrm{g} \mathrm{kg}^{-1} \mathrm{DW}$ ) at the freshwater site F2 and $55370 \mu \mathrm{g} \mathrm{kg}^{-1} \mathrm{WW}$ (or $175 \mu \mathrm{g} \mathrm{kg}^{-1} \mathrm{DW}$ ) in the estuary at $\mathrm{E} 1$. These values were higher 554 than the value of $3 \mu \mathrm{g} \mathrm{kg}^{-1}$ WW reported by Umehara et al. (2012) in Isahaya Bay, 555 Japan associated with MC concentration of $100 \mu \mathrm{gg} \mathrm{kg}^{-1} \mathrm{WW}$ in the freshwater 556 reservoir upstream. High values of MC in surface silty sediments, reaching $40 \mu \mathrm{gg}^{-1}$ 557 DW, were also reported in Curonian lagoon after a large bloom of Microcystis 558 (Paldavieciene et al 2015; Bukaveckas et al 2017). Intracellular MC measured in the sediments were most likely due to Microcystis species ( $M$. aeruginosa in particular), 560 given its dominance in the sediments. Assuming that Microcystis was the only MC 561 producer, these intracellular concentrations corresponded at both $\mathrm{F} 2$ and $\mathrm{E} 1$ to 562 cellular quotas of $160 \mathrm{fg} \mathrm{cell}^{-1}$. Higher MC quotas in sediments compared with the 563 overlying water column has already been observed in lakes where the authors have 564 suggested that MC may intervene in cells preservation reducing grazing by benthic 565 invertebrate or reducing microbial activities (Misson et al 2012). In surface 566 sediments, extracellular MC concentrations were almost 5 times higher than 567 intracellular concentrations, in contrast with the water column. This result suggests 568 either some cells lysis from individual cells or small colonies and subsequent release 569 in the porous sediments, or active transport of MC from intracellular to extracellular 570 form possibly associated with the signaling of stress conditions. Relatively high 
571 values of extracellular MC also indicated that MC degradation by bacteria or other 572 abiotic factors was not completely occurring. Hence our results indicate that 573 estuarine sediments are preserving both colonial cyanobacteria from cells lysing and 574 probably also MC from degradation. Nevertheless, these results are still preliminary 575 and there is still a need to investigate the duration of the toxins presence in 576 sediments after the bloom period as well as their presence deeper in the sediments. 577 Our results are in line with reports from Curonian lagoon where relatively high 578 sediment MC concentrations have been measured many years after a large 579 Microcystis bloom (Paldavieciene et al 2015). These results have important 580 consequences for contamination of aquatic food webs as reported for zebra mussels 581 by Paldavieciene et al (2015) and planktivorous fish by Bukaveckas et al (2017). In 582 lacustrine systems, MC can persist in sediments several years (Misson et al. 2011) 583 probably due to of the preservation conditions found in these environments (no light, 584 low temperature, anoxic condition). Biodegradation in sediments of MC-LR was 585 indeed found more rapid in aerobic than in anaerobic conditions (Grutzmacher et al 586 2010). Interestingly, Misson et al. (2012) have highlighted that benthic Microcystis 587 from 6-years sediments were able to initiate MC production implying that MC could 588 be involved in the benthic survival mechanisms of Microcystis. Here, it is evident that 589 salinity may affect significantly intra or extracellular MC in terms of degradation or 590 inducing Microcystis metabolism stimuli but no studies has examined these factors.

592 Generally, we observed a decrease of MC concentrations along the salinity gradient.

593 A gradient of MC concentration in surface sediments was also observed in Isahaya 594 Bay, Japan (Umehara et al. 2012; 2017) related to concentrations in the water 595 column with maximum values during bloom periods. Temporal variability in MC 596 concentrations in sediment is expected as demonstrated by Umehara et al. (2012; 597 2015) where the dynamics is governed by variations in the discharge from the 598 reservoir, as well as sedimentation and resuspension processes associated with tidal 599 flows. However, while we did not investigate the temporal variability, we 600 demonstrated unambiguously the presence of Microcystis colonies along the entire 601 freshwater-marine continuum, at the time of a toxic bloom in the upstream reservoir. 602 Moreover, at F2 all toxic genotypes and a high MC concentration were detected in 603 the sediment. The same applies at E1 and E2 except with a smaller MC 604 concentration. Only at the most downstream site (marine outlet) did we not detect 
605 any $\mathrm{MC}$ in the sediment in accordance with the genes analysis that suggested the 606 presence of a very small number of toxic genotypes at the time of sampling. This 607 may confirm the previous hypothesis, about the importance of F2 station to transfer 608 Microcystis in the estuary. Our results are in line with the findings of Via-Ordorika et 609 al. (2004) who reported that most M. aeruginosa colonies from several freshwater 610 lakes contained the mcyA and mcyB genes and found a positive relationship 611 between genes frequency and colony size. Our results also support the measure of 612 MC production genes as a proxy of toxic genotypes as tested by Martinez et al. 613 (2017) and Otten et al. (2015) to evaluate the toxic potential of cyanobacteria along a 614 freshwater marine continuum.

616 Interestingly, anaC was also detected at F2 revealing the presence of potentially 617 anatoxin-a producer such as Planktothrix sp. (Viaggiu et al. 2004) or 618 Dolichospermum sp. (Delvin et al. 1977). These results suggest a potential co619 occurrence between MC and anatoxin-a which has already observed in several lakes 620 (Graham et al. (2006); Sabart et al. (2015) and the co-occurrence of several 621 cyanotoxins in coastal areas (Tatters et al. 2017). This potential co-occurrence may 622 link to a high number of toxigenic species present here.

\section{Conclusions}

626 The results of this study confirm the transfer of cyanobacteria and MC from a 627 freshwater reservoir discharge, through an estuary and up to the marine outlet 628 together with the co-occurrence of both cyanobacterial cells and MC in the estuary's 629 sediments. Similarly to studies in freshwater lakes both Microcystis cells and MC 630 were found in sediments even when no cells or MC was recorded in the water 631 column at the same site, indicating that sediments integrate over time as well as 632 preserve cells from dilution and degradation. Hence the sediments act as a reservoir 633 of cyanobacteria and MC. The majority of cyanobacterial cells in sediments were 634 found in colonial form suggesting that the mucilage plays a crucial role in maintaining 635 colonies in sediments. This study highlights the survival of Microcystis cells in the 636 water column at salinities in the range 5 to 10, and in surface sediments up to a 637 salinity of 27 . MC concentrations measured here in estuarine sediments were much 638 higher than reported elsewhere in the literature. This is the first study reporting on the 
presence of mcy genes in estuarine sediments, indicating the toxicity potential of 640 estuarine sediments for benthic organisms and also as potential source to be 641 resuspended in the water column.

642

\section{Acknowledgments}

644 The authors thank Maxime Georges des Aulnois for help with field work, Marion 645 Chorin for nutrient analyses and Gorenka Bojadzija Savic for finalisation of the 646 figures. Microscopy and biochemical analyses were performed at the Experimental 647 Ecology (ECOLEX) and the Analytical (PLAY) platforms of the UMR Ecobio. The physicochemical caracteristics of the sediments were analysed by the SARM laboratory of the CRPG-CNRS in Nancy, France. This project was financially supported by the ANSES (Agence Nationale de Sécurité Sanitaire de l'Alimentation, de l'Environnement et du Travail) under the Bieautox project EST-2015-191. The helpful suggestions from the reviewers are also acknowledged.

\section{References}

Anon (2005) Anonyme ISO 20179:2005(E). Water quality - Determination of microcystins - Method using solid phase extraction (SPE) and high performance liquid chromatography (HPLC) with ultraviolet (UV) detection. International Standard ISO 20179, first edition 2005-10-01, 17 p

Bormans M, Amzil Z, Mineaud E, Brient L, Savar V, Robert E, Lance E (2019) Demonstrated transfer of cyanobacteria and cyanotoxins along a freshwater-marine continuum in France. Harmful Algae 87: 101639

Bourrelly P (1985) Les algues d'eau douce: les algues bleues et rouges (Vol. 3). Lubrecht \& Cramer Ltd.

Briand E, Escoffier N, Straub C, Sabart M, Quiblier C (2009) Spatiotemporal changes in the genetic diversity of a bloom-forming Microcystis aeruginosa (cyanobacteria) population. ISME J 3: 419-429

Briand E, Bormans M, Quiblier C, Salençon MJ, Humbert JF (2012) Evidence of the cost of the production of microcystins by Microcystis aeruginosa under differing light and nitrate environmental conditions. PLoS One 7 (1): e29981

Brient L, Lengronne M, Bertrand E, Rolland D, Sipel A, Steinmann D, Baudin I, Legeas M, Le Rouzic N, Bormans M (2008) A phycocyanin probe as a tool for monitoring cyanobacteria in freshwater bodies. J Environ Monit 10: 248-55 
Brient L, Lengronne M, Bormans M, Fastner J (2009) First occurrence of cylindrospermopsin in freshwater in France. Environmental Toxicology 24(4): 415420

Bukaveckas PA, Lesutiene J, Gaisunaite ZR, Lozys L, Olenina I, Pilkaityte R, Putys Z, Tassone S, Wood J (2017). Microcystin in aquatic food webs of the Baltic and Chesapeake Bay regions. Estuarine, Coastal and Shelf Science $191: 50-59$

Bukaveckas PA, Franklin R, Tassone S, Trache B, Egerton T (2018). Cyanobacteria and cyanotoxins at the river-estuarine transition. Harmful Algae 76: 11-21

Carey CC, Ibelings BW, Hoffmann EP, Hamilton DP, Brookes JD (2012) Ecophysiological adaptations that favour freshwater cyanobacteria in a changing climate. Water Res 46:1394-1407

Cires S, Wörmer L, Agha R, Quesada A (2013) Overwintering populations of Anabaena, Aphanizomenon and Microcystis as potential inocula for summer blooms. J Plankton Res 35(6): 1254-1266

Conley DJ (1997) Contribution of biogenic silica to the oceanic silica budget. Limnol Oceanogr 42(4): 774-777

De Pace R, Vita V, Bucci MS, Gallo P, Bruno M (2014) Microcystin contamination in sea mussel farms from the Italian southern Adriatic coast following cyanobacterial blooms in the artificial reservoir. J. of Ecosystems ID 374027

http://dx.doi.org/10.1155/2014/374027

Devlin JP, Edwards OE, Gorham PR, Hunter NR, Pike RK, Stavric B (1977) Anatoxin-a, a toxic alkaloid from Anabaena flos-aquae NRC-44h. Canadian Journal of Chemistry 55(8): 1367-1371

Dörr FA, Pinto E, Soares RM, Azevedo SMFO (2010) Microcystins in South American aquatic ecosystems: occurrence, toxicity and toxicological assays. Toxicon $56: 1247-1256$

Evans RD (1994) Empirical evidence of the importance of sediment resuspension in lakes. Hydrobiologia 284:5-12

Folger D (1972) Characteristics of estuarine sediments of the United States USGS report 2482

Fraisse S, Bormans M, Lagadeuc Y (2013) Morphofunctional traits reflect differences in phytoplankton community between rivers of contrasted flow regime. Aquat Ecol 47: 315-327 doi:10.1007/s10452-013-9446-z

Georges des Aulnois M, Roux P, Caruana A, Réveillon D, Briand E, Hervé F, Savar V, Bormans M, Amzil Z (2019) Physiological and metabolic responses of freshwater and brackish waters strains of Microcystis aeruginosa acclimated to a salinity gradient: insight into salt tolerance. Applied and Env Microbiology DOI: 10.1128/AEM.01614-19 
Gibble CM, Peacock MB, Kudela RM (2016) Evidence of freshwater algal toxins in

Grutzmacher G, Wessel G, Klitzke S, Chorus I (2010) Microcystin elimination during sediment contact. Environ Sci Technol 44: 657-662

Harke MJ, Steffen MM, Gobler CJ, Otten TG, Wilhelm SW, Wood SA, Paerl HW (2016) A review of the global ecology, genomics, and biogeography of the toxic cyanobacterium Microcystis spp. Harmful Algae 54: 4-20

Henriksen A, Selmer-Olsen AR (1970) Automatic methods for determining nitrate and nitrite in water and soil extracts. Analyst 95: 514-518

Komárek J, Anagnostidis K (2005) Süßwasserflora von Mitteleuropa, bd. 19/2: Cyanoprokaryota: Oscillatoriales (Vol. 19). Spektrum Akademischer Verlag.

Komárek J, Anagnostidis K (2013) Süßwasserflora von Mitteleuropa, bd. 19/2: Cyanoprokaryota: Heterocytous Genera (Vol. 19/3). Spektrum Akademischer Verlag.

Komárek J (2016) Review of the cyanobacterial genera implying planktic species after recent taxonomic revisions according to polyphasic methods: state as of 2014 . Hydrobiologia 764(1) : 259-270

Kravchuk ES, Ivanova EA, Gladyshev MI (2011) Spatial distribution of resting stages (akinetes) of the cyanobacteria Anabaena flos-aquae in sediments and its influence on pelagic populations. Mar Fresh Res 62: 450-461

Kruk C, Segura AM, Nogueira L, Alcántara I, Calliaria D, Martínez de la Escalerad G, Carballoa C, Cabreraa C, Sarthoua F, Scavone P, Piccini C (2017) A multilevel traitbased approach to the ecological performance of Microcystis aeruginosa complex from headwaters to the ocean. Harmful Algae 70: 23-36

Labry C, Delmas D, Youenou A, Quere J, Leynaert A, Fraisse S, Raimonet M, Ragueneau O (2016) High alkaline phosphatase activity in phosphate replete waters: The case of two macrotidal estuaries. Limnol Oceanogr 61:1513-1529

Lance E, Brient L, Carpentier A, Acou A, Marion L, Bormans M, Gérard C (2010) Impact of toxic cyanobacteria on gastropods and microcystin accumulation in a eutrophic lake (Grand-Lieu, France) with special reference to Physa (= Physella) acuta. Science of the Total Environment 408: 3560-3568

Legrand B, Lamarque A, Sabart M, Deltour D (2016) Characterization of akinetes from cyanobacterial strains and lake sediment: A study of their resistance and toxic potential. Harmful Algae 59: 42-50 
Legrand B, Le Jeune AH, Colombet J, Thouvenot A, Latour D (2017) Akinetes May Be Representative of Past Nostocalean Blooms: a Case Study of Their Benthic Spatiotemporal Distribution and Potential for Germination in a Eutrophic Lake. Appl Environ Microbiol 83:e01571-17

Legrand B, Miras Y, Beauger A, Dussauze M, Latour D (2019)_Akinetes and ancient 6700-year-old core from a eutrophic lake. Science of the Total Environment 687: 1369-1380

Lehman PW, Boyer G, Hall C, Waller S, Gehrts K (2005) Distribution and toxicity of a new colonial Microcystis aeruginosa bloom in the San Francisco Bay Estuary, California. Hydrobiologia 541: 87-99

Le Moal M, Gascuel-Odoux C, Menesquen A, Souchon Y, Etrillard C, Levain A, Moatar F, Pannard A, Souchu P, Lefebvre A, Pinay G (2019) Eutrophication: A new wine in an old bottle? Science of the Total Environment DOI:10.1016/i.scitotenv.2018.09.139

Maavara T, Dürr HH, Van Cappellen P (2014) Worldwide retention of nutrient silicon by river damming: From sparse data set to global estimate. Global Biogeochem Cycles $28: 842-855$ doi:10.1002/2014GB004875

Martínez de la Escalera G, Kruk C, Segurad AM, Nogueira L, Alcántara I, Piccini C (2017) Dynamics of toxic genotypes of Microcystis aeruginosa complex (MAC) through a wide freshwater to marine environmental gradient. Harmful Algae 62 :7383

Merel S, Walker D, Chicana R, Snyder S, Baurés E, Thomas O (2013) State of knowledge and concerns on cyanobacterial blooms and cyanotoxins. Environ Int 59: 303-327

Meriluoto J, Blaha L, Bojadzija G, Bormans M, Brient L, Codd GA, Drobac D, Faassen EJ, Fastner J, Hiskia A, lbelings BW, Kaloudis T, Kokocinski M, Kurmayer R, Pantelić D, Quesada A, Salmaso N, Tokodi N, Triantis TM, Visser PM, Svirčev Z (2017) Toxic cyanobacteria and cyanotoxins in European waters - recent progress achieved through the CYANOCOST Action and challenges for further research. Advances in Oceanography and Limnology 8(1) DOI: 10.4081/aiol.2017.6429

Misson B, Sabart M, Amblard C, Latour D (2011) Involvement of microcystins and colony size in the benthic recruitment of the cyanobacterium Microcystis (Cyanophyceae). Journal of Phycology 47:42-51

Misson B, Sabart M, Amblard C, Latour D (2012) Benthic survival of Microcystis: long-term viability and ability to transcribe microcystin genes. Harmful Algae 13: 2025.

Ndlela LL, Oberholster PJ, Van Wyk JH, Cheng PH (2016) An overview of cyanobacterial bloom occurrences and research in Africa over the last decade. Harmful Algae 60 : 11-26 
Nubel U, Garcia-Pichel F, Muyzer G (1997) PCR primers to amplify 16SrRNA genes

Omidi A, Esterhuizen-Londt M, Pflugmacher S (2017) Still challenging: the ecological function of the cyanobacterial toxin microcystin - What we know so far. Toxin Reviews 37: Issue 2.

O'Neil JM, Davis TW, Burford MA, Gobler CJ (2012) The rise of harmful cyanobacteria blooms: The potential roles of eutrophication and climate change Harmful Algae 14 : 313-334

Orr PT, Jones GJ (1998) Relationship between microcystin production and cell division rates in nitrogen-limited Microcystis aeruginosa cultures. Limnol Oceanogr 43: 1604-1614

Orr PT, Jones GJ, Douglas GB (2004) Response of cultured Microcystis aeruginosa from the Swan River, Australia, to elevated salt concentration and consequences for bloom and toxin management in estuaries. Mar Freshw Res 55 (3) : 277-283

Ortiz et al., (2017) A high throughput targeted and non-targeted method for the analysis of microcystins and anatoxin-A using on-line solid phase extraction coupled to liquid chromatography-quadrupole time-of-flight high resolution mass spectrometry. Analytical and Bioanalytical Chemistry 409 (21): 4959

Otten TG, Crosswell JR, Mackey S, Dreher TW (2015) Application of molecular tools for microbial source tracking and public health risk assessment of a Microcystis bloom traversing $300 \mathrm{~km}$ of the Klamath River. Harmful Algae 46 : 71-81

Paerl HW (2018) Mitigating Toxic Planktonic Cyanobacterial Blooms in Aquatic Ecosystems Facing Increasing Anthropogenic and Climatic Pressures. Toxins 10: 76 doi:10.3390/toxins10020076

Paerl HW, Otten TG, Kudela R (2018) Mitigating the Expansion of Harmful Algal Blooms Across the Freshwater-to-Marine Continuum. Environ Sci Technol 52 : 5519-5529

Paldavičiene A, Mazur-Marzec H, Razinokovas A (2009) Toxic cyanobacteria blooms in the Lithuanian part of the Curonian Lagoon. Oceanologia 51 (2) : 203-216

Paldavičiene A, Zaiko A, Mazur-Marzec H, Razinokovas-Baziukas A (2015) Bioaccumulation of microcystins in invasive bivalves: a case study from the boreal lagoon ecosystem. Oceanologia 57: 93- 101

Pannard A, Guislain A, Chorin M, Mahé S, Bouger G, Crave A, Le Rouzic B, Bormans M (2018) Phosphorus more than temperature controls the phytoplankton community in a deep quarry lake: a combined field and laboratory approach. Inland Waters, DOI:10.1080/20442041.2018.1424097 
Peacock MB, Gibble CM, Senn DB, Cloern JE, Kudela RM (2018) Blurred lines: 881 Multiple freshwater and marine algal toxins at the land-sea interface of San Francisco Bay, California. Harmful Algae 73 : 138-147

Pham TL, Utsumi M (2018) An overview of the accumulation of microcystins in aquatic ecosystems. Journal of Environmental Management 213: 520-529

Pitois F, Thoraval I, Baurès E, Thomas O (2014) Geographical Patterns in Cyanobacteria Distribution: Climate Influence at Regional Scale. Toxins 6: 509-522

Pitois F, Fastner J, Pagotto C, Dechesne M (2018) Multi-Toxin Occurrences in Ten French Water Resource Reservoirs. Toxins 10: 283

Preece EP, Moore BC, Hardy FJ (2015) Ecotoxicology and Environmental Safety Transfer of microcystin from freshwater lakes to Puget Sound, WA and toxin accumulation in marine mussels (Mytilus trossulus). Ecotoxicology and Environmental Safety 122: 98-105

897 Preece EP, Hardy FJ, Moore BC, Bryan M (2017) A review of microcystin detections 898 in Estuarine and Marine waters: Environmental implications and human health risk. 899 Harmful Algae $61: 31-45$

Puddick J, Prinsep MR, Wood SA, Kaufononga SAF, Cary SC, Hamilton DP (2014) High Levels of Structural Diversity Observed in Microcystins from Microcystis CAWBG11 and Characterization of Six New Microcystin Congeners. Mar Drugs 12 : 5372-5395; doi:10.3390/md12115372

Reynolds CS (2006) Ecology of Phytoplankton. Cambridge University Press, Cambridge, UK

Rigosi A, Carey CC, Ibelings BW, Brookes JD (2014) The interaction between climate warming and eutrophication to promote cyanobacteria is dependent on trophic state and varies among taxa. Limnol Oceanogr 59(1): 99-114

Robson BJ, Hamilton DP (2003) Summer flow event induces a cyanobacterial bloom in a seasonal western Australia estuary. Mar Freshw Res 54: 139-151

Sabart M, Crenn K, Perrière F, Abila A, Leremboure M, Colombet J, ... Latour D (2015) Co-occurrence of microcystin and anatoxin-a in the freshwater lake Aydat (France): Analytical and molecular approaches during a three-year survey. Harmful Algae 48: 12-20

Taş S, Okus E, Aslan-Yilmaz A (2006) The blooms of a cyanobacterium, Microcystis cf. aeruginosa in a severely polluted estuary, the Golden Horn, Turkey. Estuar Coast. Shelf Sci 68, : 593-599

Tatters AO, Howard MDA, Nagoda C, Busse L, Gellene AG, Caron DA (2017) Multiple stressors at the land-sea interface: cyanotoxins at the land-sea interface in the Southern California Bight. Toxins doi:http://dx.doi.org/10.3390/ toxins9030095. 
Tillett D, Dittmann E, Erhard M, von Döhren H, Börner T, Neilan BA (2000) Structural organization of microcystin biosynthesis in Microcystis aeruginosa PCC7806: an cyanobacterium Microcystis aeruginosa. Aquat Microb Ecol 46: 117-123

Umehara A, Tsutsumi $\mathrm{H}$, Takahashi $\mathrm{T}$ (2012) Blooming of Microcystis aeruginosa in the reservoir of the reclaimed land and discharge of microcystins to Isahaya Bay (Japan). Environ Sci Pollut Res 19: 3257-3267

Umehara A, Komorita T, Tai A, Takahashi T, Orita R, Tsutsumi H (2015) Short-term dynamics of cyanobacterial toxins (microcystins) following a discharge from a coastal reservoir in Isahaya Bay, Japan. Marine Pollution Bulletin 92: 73-79.

Umehara A, Takahashi T, Komorita T, Orita R, Choi JW, Takenaka R, Mabuchi R, Park HD, Tsutsumi H (2017) Widespread dispersal and bio-accumulation of toxic microcystins in benthic marine ecosystems. Chemosphere $167: 492-500$

Verspagen JMH, Snelder EOFM, Visser PM, Jöhnk KD, lbelings BW, Mur LR, Huisman J (2005) Benthic-pelagic coupling in the population dynamics of the harmful cyanobacterium Microcystis. Freshw Biol 50: 854-867

https://doi.org/10.1111/j.1365-2427.2005.01368.x.

Verspagen JMH, Passarge J, Jöhnk KD, Visser PM, Peperzak L, Boers P, Laanbroek HJ, Huisman J (2006) Water management strategies against toxic Microcystis blooms in the Dutch delta. Ecol Appl 16 : 313-327

Vezie C, Brient L, Sivonen K, Bertru G, Lefeuvre JC, Salkinoja-Salonen M (1998) Variation of microcystin content of cyanobacterial blooms and isolated strains in Lake Grand-Lieu (France). Microb Ecol 35:126-35

Viaggiu E, Melchiorre S, Volpi F, Di Corcia A, Mancini R, Garibaldi L, Bruno M (2004) Anatoxin-a toxin in the cyanobacterium Planktothrix rubescens from a fishing pond in northern Italy. Environmental Toxicology: An International Journal 19(3): 191-197

Via-Ordorika L, Fastner J, Kurmayer R, Hisbergues M, Dittmann E, Komarek J, Erhard M, Chorus I (2004) Distribution of Microcystin-Producing and NonMicrocystin-Producing Microcystis sp. in European Freshwater Bodies: Detection of Microcystins and Microcystin Genes in Individual Colonies. Systematic and Applied Microbiology 27(5): 592-602

Wood R (2016) Acute animal and human poisonings from cyanotoxin exposure $-\mathrm{A}$ review of the literature. Environment International $91: 276-282$

Wood SA, Rueckert A, Hamilton DP, Cary SC, Dietrich DR (2011). Switching toxin production on and off : intermittent microcystin synthesis in a Microcystis bloom. Env. Microbiol. Report 3(1) : 118-124 
979 Xiao M, Li M, Reynolds CS (2018) Colony formation in the cyanobacterium 980 Microcystis. Biol Rev 93: 1399-1420

981 